\title{
Penerapan Five Stage Conceptual Teaching Model untuk Meningkatkan Prestasi Belajar dan Konsistensi Ilmiah pada Siswa SMA
}

\author{
Resta Krishnayanti $^{\text {a)}}$, Selly Feranie ${ }^{\text {b) }}$, I Made Padri \\ Universitas Pendidikan Indonesia, Jl. Dr. Setiabudhi no. 229 Bandung, 40154, Jawa Barat \\ Email: ${ }^{\text {a) }}$ rkrishnayanti@gmail.com, ${ }^{\text {b) }}$ sferanie@yahoo.com
}

\begin{abstract}
Five Stage Conceptual Teaching Model has been applied to improve learning achievement and scientific consistency of the static fluid material. Material fluid static decomposed into 8 subconcepts ie, the hydrostatic pressure (the relationship with depth), the hydrostatic pressure (the relationship of density), the principal legal hydrostatics, the principle of Pascal, buoyancy, floating, floating and sinking, surface tension, and capillarity. The method used is one group pretest-posttest design with a sample of one class X of SMAN 9 Bandung consisting of 36 students. Unuk form of a test used to measure scientific consistency is using Three Tier Test based multi representasion where each theme using 3 different representations, namely verbal, images, and mathematical. The tests used to measure student achievement using a multiplechoice test. Results from this study were obtained value gain $(\langle\mathrm{g}\rangle)$ scientific consistency of 0.53 which are in the moderate category and value gain $(<\mathrm{g}\rangle)$ the learning achievement of 0.69 and be in the medium category. The highest increase in the number of students who are in the scientific consistency sub concept of hydrostatic pressure. This is because during the learning process of students conduct experiments on these concepts so that students explore their own knowledge and students use many representations. While the lowest increase is in sub concept of floating, floating and sinking.
\end{abstract}

Keywords: scientific consistency, academic achievement, Five Stage Teaching Conceptual, Three Tier Test

\begin{abstract}
Abstrak
Five Stage Conceptual Teaching Model telah diterapkan untuk meningkatkan prestasi belajar dan konsistensi ilmiah pada materi fluida statis. Materi fluida statis diuraikan ke dalam 8 subkonsep yaitu, tekanan hidrostatis (hubungan dengan kedalaman), tekanan hidrostatis (hubungan dengan massa jenis), hukum pokok hidrostatika, prinsip Pascal, gaya apung, terapung, melayang, dan tenggelam, tegangan permukaan, dan kapilaritas.Metode penelitian yang digunakan yaitu one group pre test-post test design dengan sampel salah satu kelas X di SMAN 9 Bandung yang terdiri dari 36 siswa. Bentuk tes yang digunakan unuk mengukur konsistensi ilmiah adalah menggunakan Three Tier Test berbasis multirepresentasi dimana setiap tema menggunakan 3 representasi yang berbeda, yaitu verbal, gambar, dan matematis. Tes yang digunakan untuk mengukur prestasi belajar siswa menggunakan tes pilihan ganda. Hasil dari penelitian ini diperoleh nilai gain $(\langle\mathrm{g}\rangle)$ konsistensi ilmiah sebesar 0,53 yang berada dalam kategori sedang dan nilai gain $(<\mathrm{g}\rangle)$ prestasi belajar sebesar 0,69 dan berada dalam kategori sedang. Peningkatan jumlah siswa paling tinggi yang konsistensi ilmiah berada pada
\end{abstract}


sub konsep tekanan hidrostatis. Hal ini dikarenakan saat proses pembelajaran siswa melakukan percobaan mengenai konsep-konsep tersebut sehingga siswa menggali sendiri pengetahuannya dan siswa menggunakan banyak representasi. Sedangkan peningkatan paling rendah ada pada sub konsep terapung, melayang, dan tenggelam.

Kata-kata kunci: konsistensi ilmiah, prestasi belajar, Five Stage Conceptual Teaching, Three Tier Test

\section{PENDAHULUAN}

Suatu ilmu, dalam Fisika terdapat berbagai macam konsep. Dalam ilmu Fisika pemahaman konsep sangat penting untuk membangun proses berpikir siswa dalam memahami permasalahanpermasalahan sederhana hingga yang rumit.

Hingga saat ini Fisika merupakan bagian dari Ilmu Pengetahuan Alam (IPA) yang dianggap siswa sebagai mata pelajaran yang sangat sulit (Angell et al, 2004). Hal ini dapat dilihat dari rendahnya prestasi belajar yang dicapai siswa. Rendahnya prestasi belajar muncul karena penguasaan konsep yang tidak sinkron antara konsepsi konkret dan konsepsi formal. Penguasaan konsep yang tidak sinkron antara konsepsi konkret dan konsepsi formal sering mengakibatkan adanya miskonsepsi dan ketidak konsistenan pada diri siswa. Selain itu, siswa belum mampu membentuk pengetahuan secara mandiri dan kurang aktif untuk membangun pengetahuan karena belum terbentuknya pemahaman yang utuh dalam diri. Fisika dianggap sulit karena siswa dituntut untuk memahami berbagai representasi dan pemahaman konsep secara bersamaan.

Berdasarkan uraian permasalahan di atas, maka peneliti berniat untuk melakukan suatu penelitian yang dapat meningkatkan konsistensi ilmiah dan prestasi belajar. Peneliti mengadopsi pembelajaran Five Stage Conceptual Teaching Model yang meliputi orientasi, elisitasi, restrukturisasi, aplikasi, dan review (Driver and Oldham, 1986) untuk penelitian ini. Pada model pembelajaran tersebut terdapat tahap-tahap dimana siswa diminta untuk mengemukakan pengetahuan awal, kemudian pemaparan situasi konflik dimana siswa melakukan kegiatan untuk membuktikan pengetahuan awal mereka sesuai kebenaran ilmiah, setelah itu berdasarkan pengetahuan baru yang telah diperoleh, siswa mengatur kembali pengetahuan awal mereka berdasarkan pengetahuan yang baru, dan tahap terakhir siswa diberikan permasalahan mengenai konsep tersebut dengan situasi yang baru. Berdasarkan penelitian yang telah dilakukan oleh Rofiuddin (2014) didapatkan bahwa penerapan Five Stage Conceptual Teaching Model telah meningkatkan hasil belajar kognitif siswa. Dalam penelitian yang akan dilakukan, peneliti akan melibatkan penggunaan representasi pada setiap tahap pembelajarannya. Hal ini dilakukan untuk membantu proses pembelajaran agar siswa mampu memahami konsep yang dipelajari dan mampu menyelesaikan permasalahan suatu konsep pada situasi yang baru.

Rumusan penelitian ini adalah: 1) Bagaimana peningkatan prestasi belajar siswa setelah penerapan Five Stage Conceptual Teaching Model? 2) Bagaimana peningkatan konsistensi ilmiah siswa setelah penerapan Five Stage Conceptual Teaching Model?

\section{METODE PENELITIAN}

Metode yang digunakan dalam penelitian ini adalah pre-experimental design. Alasan penggunaan metode ini adalah karena adanya variabel luar yang ikut berpengaruh terhadap terbentuknya variabel dependen/variabel terikat hasil penelitian (Sugiyono, 2009:74). Sedangkan desain penelitian yang digunakan adalah one group pre test-post test design. One group pre test-post test design adalah eksperimen yang dilaksanakan pada satu kelompok saja sebagai kelompok eksperimen tanpa kelompok pembanding. Penelitian ini dilakukan pada kelas X di salah satu SMA Negeri di kota Bandung dan jumlah sampel pada kelas tersebut sebanyak 36 orang.

TABEL 1. Desain Penelitian

\begin{tabular}{ccc}
\hline Pretest & Treatment & Posttest \\
\hline $\mathrm{O}_{1}$ & $\mathrm{X}$ & $\mathrm{O}_{2}$ \\
\hline
\end{tabular}




\section{Konsistensi Ilmiah dan Prestasi Belajar}

Konsistensi ilmiah siswa diujikan dengan instrumen berbentuk Three-Tier Multiple Choice Test berbasis multirepresentasi. Untuk setiap konsep terdiri dari tiga representasi yang merepresentasikan konsep yang sama.

- Dalam teknik penskoran dari soal tes multirepresentasi (21 item tes dengan 7 tema) pada jurnal Relations between representational consistency, conceptual understanding of the force concept, and scientific reasoning untuk menentukan baik konsistensi ilmiah maupun representasi, maka digunakan penskoran untuk setiap tema soal sebagai berikut. Dua poin, bila memilih jawaban yang sama berdasarkan pemberian tiga soal dalam konsep yang sama namun konteks yang berbeda.

- Satu poin, bila memilih jawaban yang sama berdasarkan pemberian dua soal dalam konsep yang sama namun konteks yang berbeda.

- Nol poin, bila tidak memilih jawaban yang sama berdasarkan pemberian tiga soal dalam konsep yang sama namun konteks yang berbeda.

Karena soal berbentuk Three Tier Test, maka penilaian untuk konsistensi ilmiah pada setiap tema atau label konsep adalah sebagai berikut.

TABEL 2. Analisis Konsistensi Ilmiah Menggunakan Three Tier Test

\begin{tabular}{cl}
\hline Skor & \multicolumn{1}{c}{ Kriteria } \\
\hline 2 & $\begin{array}{l}\text { Bila memilih jawaban yang benar pada bagian pertama (first tier), } \\
\text { bagian kedua (second tier), dan bagian ketiga (third tier) berdasarkan } \\
\text { pemberian tiga soal dalam konsep yang sama namun konteks yang } \\
\text { berbeda. }\end{array}$ \\
& $\begin{array}{l}\text { Bila memilih jawaban yang benar pada bagian pertama (first tier), } \\
\text { bagian kedua (second tier), dan bagian ketiga (third tier) berdasarkan } \\
\text { pemberian dua soal dalam konsep yang sama namun konteks yang } \\
\text { berbeda. } \\
\text { Bila tidak memilih jawaban yang benar pada bagian pertama (first } \\
\text { tier), bagian kedua (second tier), dan bagian ketiga (third tier) } \\
\text { berdasarkan pemberian tiga soal dalam konsep yang sama namun } \\
\text { konteks yang berbeda. }\end{array}$ \\
\hline
\end{tabular}

Berikutnya perhitungan nilai konsistensi ilmiah siswa dihitung dengan cara:

$$
\text { nilai }=\frac{\text { skor yang didapat }}{\text { jumlah skor maksimum seluruh tema }} \times 100
$$

Rata-rata konsistensi ilmiah seluruh siswa dihitung dengan cara:

$$
\text { rata }- \text { rata }=\frac{\text { nilai seluruh siswa }}{\text { jumlah siswa }}
$$

Untuk prestasi belajar, tes yang digunakan adalah tes pilihan ganda. Jika jawaban benar maka skor 1 dan jika salah adalah 0 .

\section{HASIL DAN PEMBAHASAN}

\section{1) Prestasi Belajar}

Prestasi belajar diukur menggunakan tes pilihan ganda. Jika jawaban benar maka skor adalah 1 dan jika salah maka skor adalah 0. Skor prestasi belajar siswa dibandingkan antara pre test dan post test, kemudian dihitung hingga diperoleh nilai peningkatan (n-gain) yang kemudian diklasifikasikan berdasarkan analisis Hake (1999).

Peningkatan prestasi belajar berdasarkan hasil pretest dan posttest adalah sebesar 51,63 dengan nilai rata-rata pre test dan post test secara berturut-turut adalah 24,77 dan 76,40 . Nilai gain yang diperoleh berada pada kategori sedang (Hake, 1999) dengan nilai sebesar 0,69. Sehingga dapat 
disimpulkan bahwa prestasi belajar siswa setelah mendapat treatment pembelajaran Five Stage Conceptual Teaching Model menunjukkan peningkatan dengan bukti nilai tertinggi pada post test adalah 91,67 dari rentang 0 hingga 100; yang berarti hanya terdapat dua soal yang dijawab salah oleh siswa dibandingkan dengan seluruh jawaban salah dari total dua puluh empat pertanyaan sehingga mendapatkan nilai dibawah skor tertinggi selama pelaksanaan pre test. Nilai terendah selama pelaksanaan pre test dan post test adalah 0 dan 54,17. Sebagian besar siswa mencapai hasil post test lebih baik dari pre test dengan menjawab pertanyaan secara benar sebanyak tiga belas pertanyaan atau hampir separuh dari total pertanyaan. Analisis prestasi belajar ditekankan pada peningkatan prestasi belajar di setiap label konsep pada materi fluida statis yang terdiri dari tekanan hidrostatis (hubungan dengan kedalaman), tekanan hidrostatis (hubungan dengan massa jenis), hukum pokok hidrostatika, prinsip Pascal, gaya apung, terapung, melayang, dan tenggelam, tegangan permukaan, dan kapilaritas yang dideskripsikan dan direpresentasikan oleh TABEL 3. dibawah ini.

TABEL 3. Rekapitulasi Prestasi Belajar pada Tiap Label Konsep

\begin{tabular}{|c|c|c|c|c|}
\hline $\begin{array}{c}\text { Tema Prestasi } \\
\text { Belajar }\end{array}$ & $\begin{array}{c}\text { Jumlah } \\
\text { Soal }\end{array}$ & $\mathbf{N}$ & N-Gain & Klasifikasi \\
\hline $\begin{array}{c}\text { Tekanan } \\
\text { Hidrostatis } \\
\text { (Hubungan dengan } \\
\text { Kedalaman) }\end{array}$ & 3 & & 0,8956 & tinggi \\
\hline $\begin{array}{c}\text { Tekanan } \\
\text { Hidrostatis } \\
\text { (Hubungan dengan } \\
\text { Massa Jenis } \\
\text { Fluida) }\end{array}$ & 3 & & 0,8196 & tinggi \\
\hline $\begin{array}{c}\text { Hukum Pokok } \\
\text { Hidrostatika }\end{array}$ & 3 & 36 & 0,9602 & tinggi \\
\hline Prinsip Pascal & 3 & & 0,642 & sedang \\
\hline Gaya Apung & 3 & & 0,8334 & tinggi \\
\hline $\begin{array}{l}\text { Terapung, } \\
\text { Melayang, dan } \\
\text { Tenggelam }\end{array}$ & 3 & & 0,3295 & sedang \\
\hline $\begin{array}{l}\text { Tegangan } \\
\text { Permukaan }\end{array}$ & 3 & & 0,5377 & sedang \\
\hline Kapilaritas & 3 & & 0,63 & sedang \\
\hline
\end{tabular}

\section{2) Konsistensi Ilmiah}

Nilai konsistensi ilmiah siswa diperoleh dengan memberikan pre test dan post test. Skor konsistensi ilmiah dianalisis berdasarkan tingkat jawaban dan keyakinan siswa pada 3 (tiga) bentuk representasi. Hasil konsistensi ilmiah siswa saat pre test dan post test dijelaskan pada tabel 4.3 yang menjelaskan rata-rata konsistensi ilmiah siswa saat pre test dan post test. Hasil menunjukkan bahwa saat pre test rata-rata nilai konsistensi ilmiah siswa adalah 13,60 dan setelah diberikan treatment terdapat peningkatan sebesar 45,48 dan memiliki nilai gain yang dinormalisasi sebesar 0,52 dengan kategori sedang.

Nilai rata-rata konsistensi ilmiah dibandingkan saat pre test dan post test untuk setiap konsep dalam materi fluida statis yang terdiri atas tekanan hidrostatis (hubungan tekanan dengan kedalaman), tekanan hidrostatis (hubungan dengan massa jenis), hukum pokok hidrostatika, prinsip Pascal, gaya apung, terapung, melayang, dan tenggelam, tegangan permukaan, dan kapilaritas dengan membandingkan nilai antara pre test dan post test. Selanjutnya besar peningkatan (n-gain) pada setiap 
konsep yang diklasifikasikan berdasarkan analisis gain oleh Hake (1999). Berdasarkan perhitungan nilai gain yang dinormalisasi didapatkan nilai peningkatan untuk setiap konsep. Untuk konsep tekanan hidrostatis (hubungan dengan kedalaman) memiliki nilai gain yang telah dinormalisasi sebesar 0,82 dan berdasarkan klasifikasi menurut Hake (1999) peningkatan tersebut berada dalam kategori tinggi. Nilai gain ini merupakan nilai gain yang paling besar diantara konsep lainnya. Selanjutnya, konsep tekanan hidrostatis (hubungan dengan massa jenis fluida) memiliki nilai gain yang telah dinormalisasi sebesar 0,53 dan berada dalam kategori sedang. Konsep hukum pokok hidrostatika memiliki nilai gain yang dinormalisasi sebesar 0,75 dan berada dalam kategori tinggi. Prinsip Pascal memiliki nilai gain sebesar 0,32 dan berada dalam kategori sedang. Untuk gaya apung nilai gain yang diperoleh berada dalam kategori tinggi dengan nilai sebesar 0,75 . Konsep selanjutnya adalah terapung, melayang, dan tenggelam yang memiliki nilai gain sebesar 0,32 dan berada dalam kategori sedang. Konsep tegangan permukaan memiliki nilai gain sebesar 0,41 dan berada pada kategori sedang. Konsep terakhir pada materi fluida statis dalam penelitian ini adalah kapilaritas yang memiliki nilai gain sebesar 0,40 dan berada pada kategori sedang. Jumlah siswa yang konsisten saat pre test dan post test dapat dilihat pada gambar 1.

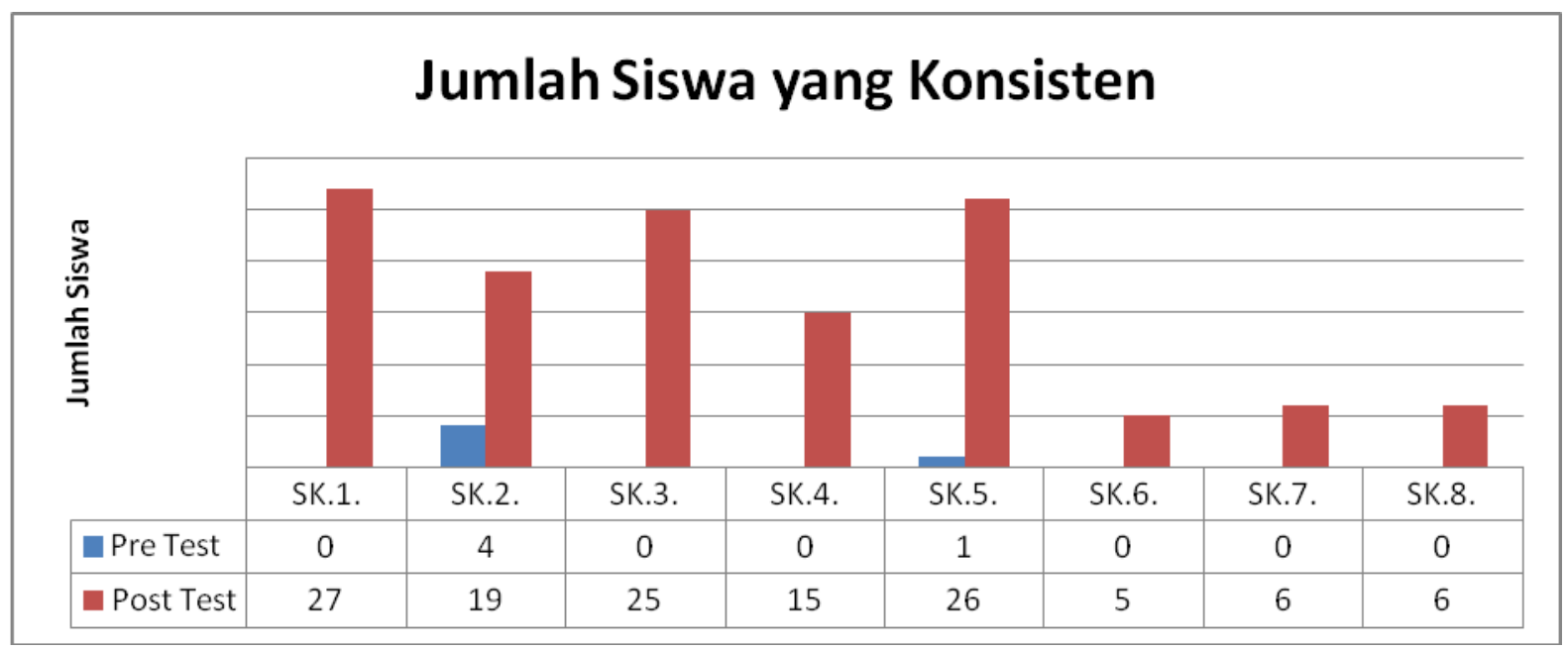

GAMBAR 1. Peningkatan Jumlah Siswa yang Konsisten Ilmiah saat Pre Test dan Post Test.

Berdasarkan hasil pada gambar 1 mengenai jumlah siswa yang konsisten saat pre test dan post test pada setiap sub konsep yang terdiri dari :

- SK 1 : Tekanan Hidrostatis (hubungan dengan kedalaman)

- SK 2 : Tekanan Hidrostatis (hubungan dengan massa jenis)

- SK 3 : Hukum Pokok Hidrostatika

- SK 4 : Prinsip Pascal

- SK 5 : Gaya Apung

- SK 6 : Terapung, melayang dan tenggelam

- SK 7 : Tegangan Permukaan

- SK 8 : Kapilaritas

Untuk SK 1 jumlah siswa yang berada pada tingkat konsisten naik dari 0 menjadi 27 siswa, sehingga siswa yang masih berada pada tingkat tidak konsisten adalah sebesar 9 siswa. Untuk SK 2 setelah diberikan pembelajaran Five Stage Conceptual Teaching Model, jumlah siswa yang berada pada tingkat konsisten naik dari 4 menjadi 19 siswa, sisanya sebanyak 17 siswa masih berada pada tingkat tidak konsisten. Selanjutnya pada SK 3, jumlah siswa yang berada pada tingkat konsisten naik dari 0 menjadi 25 siswa, dan masih ada 11 siswa yang berada pada tingkat tidak konsisten. Pada SK 4 jumlah siswa yang berada pada tingkat konsisten naik dari 0 menjadi 15 siswa, dan sisanya sebanyak 21 siswa masih belum konsisten. Pada SK 5 jumlah siswa yang berada pada tingkat konsisten naik dari 1 menjadi 26 siswa, dan sisanya 10 siswa masih belum konsisten. Untuk SK 6 jumlah siswa yang berada pada tingkat konsisten naik dari 0 menjadi 5 siswa, sisanya sebanyak 31 siswa masih belum konsisten. Untuk SK 7 jumlah siswa yang berada pada tingkat konsistensi naik dari 0 menjadi 
6 siswa, dan 30 siswa belum konsisten. Pada SK 8 jumlah siswa pada tingkat konsistensi naik dari 0 menjadi 6 siswa.

Berdasarkan hasil tersebut peningkatan tertinggi terjadi pada konsep SK 1, SK 2, SK 3, SK 4, dan SK 5. Hal ini disebabkan karena saat proses pembelajaran selain guru menyajikan video, demonstrasi, representasi dan animasi, siswa juga melakukan kegiatan percobaan. Sehingga siswa menggali sendiri pengetahuannya terhadap konsep tersebut, membuat sendiri representasi yang diminta dan pembelajaran tersebut menjadi bermakna bagi siswa untuk lebih memahami dan mengerti, meskipun diberikan konsep dengan situasi yang baru namun siswa mampu menyelesaikan permasalahan tersebut. Untuk konsep SK 6, SK 7, dan SK 8 peningkatan konsistensi ilmiah pada siswa masih sedikit. Hal ini dikarenakan, saat proses pembelajaran tidak ada kegiatan percobaan yang memfasilitasi siswa untuk memperoleh pengetahuan. Pembelajaran hanya dilakukan dengan cara berdiskusi, pemberian animasi, dan penjelasan guru. Hal ini menyebabkan siswa masih belum konsisten saat diberikan permasalahan baru siswa untuk lebih memahami dan mengerti, meskipun diberikan konsep dengan situasi yang baru namun siswa mampu menyelesaikan permasalahan tersebut.

\section{KESIMPULAN}

Penelitian ini memiliki tujuan utama untuk mengetahui prestasi belajar dan konsistensi ilmiah sebelum dan setelah penerapan Five Stage Conceptual Teaching Model. Peningkatan prestasi belajar setelah diberikan treatment adalah sebesar 51,63 dan memiliki nilai gain yang dinormalisasi sebesar 0,69 yang berada dalam kategori sedang. Peningkatan konsistensi ilmiah setelah penerapan Five Stage Conceptual Teaching Model adalah sebesar 45,48 dan memiliki nilai gain yang dinormalisasi sebesar 0,53 yang berada dalam kategori sedang. Jumlah peningkatan siswa yang paling besar dalam konsistensi ilmiah adalah pada konsep tekanan hidrostatis (hubungan dengan kedalaman dan massa jenis), hukum pokok hidrostatika, prinsip Pascal, dan gaya apung. Hal ini dikarenakan dalam proses pembelajaran, selain pemberian video, demonstrasi, dan animasi, siswa juga melakukan kegiatan percobaan untuk menggali sendiri pengetahuannya sehingga siswa lebih memahami dan memiliki daya ingat yang lama terhadap konsep-konsep tersebut.

\section{UCAPAN TERIMAKASIH}

Untuk Bapak Deni Cutarna yang telah memberikan izin untuk melakukan penelitian di kelas $\mathrm{X}$ MIA 2 SMAN 9 Bandung, serta siswa-siswa X MIA 2. Semoga kalian menjadi anak yang sukses. Ucapan terimakasih juga disampaikan kepada civitas Universitas Pendidikan Indonesia (UPI) yang telah memberikan bantuan dana penelitian melalui kegiatan Hibah Bersaing 2014.

\section{REFERENSI}

Che Hung Lin, P. L. (2010). Utilizing A Concept Map As The Teaching Strategy Based On Conceptual Change Theory For The Course Information Technology And Society . Joint International IGIP-SEFI Annual Conference 2010, Trnava, Slovakia .

Nieminen, P., Savinainen, A., \& Viiri, J. (2010). Force Concept Inventory-based multiple-choice test for investigating students' representational consistency. PHYSICAL REVIEW SPECIAL TOPICS - PHYSICS EDUCATION RESEARCH 6, 020109.

Nieminen, P., Savinainen, A., \& Viiri, J. (2012). Relations between representational consistency, conceptual understanding of the force concept, and scientific reasoning. PHYSICAL REVIEW SPECIAL TOPICS - PHYSICS EDUCATION RESEARCH 8, 010123.

Rofiuddin, Muhammad Rizqi. (2013). Application Of Five-Stage Conceptual Teaching Model Utilizing Cmap Tools To Analyza Conceptual Change And Cognitive Learning Outcomes on Light and Optics Topic. Skripsi. Jurusan International Program On Science Education. Universitas Pendidikan Indonesia. Bandung.

Sukmadinata, N. S. (2012). Metode Penelitian Pendidikan. Bandung: PT. Remaja Rosdakarya. 